\title{
Risk factors associated with hepatitis B virus infection among pregnant women attending antenatal clinic at Felegehiwot referral hospital, Northwest Ethiopia, 2018: an institution based cross sectional study
}

\author{
Getnet Gedefaw ${ }^{1 *} \mathbb{D}$, Fikadu Waltengus ${ }^{2}$, Almaz Akililu² and Kihinetu Gelaye ${ }^{2}$
}

\begin{abstract}
Objective: This study aimed to determine the magnitude of serum $\mathrm{HBs} A g$ and the risk factors for hepatitis B virus infection among pregnant women in Bahir Dar. An institution based cross sectional study was implemented from February 1 to May 1, 2018 among 338 pregnant women attending antenatal care clinic at Felegehiwot referral hospital, Bahir Dar, 2018. Systematic random sampling technique was implemented. Blood sample was taken from 338 study participants and serum was tested for hepatitis B surface antigen (HBsAg) using Enzyme Linked ImmunoSorbent Assay.

Results: The overall prevalence of hepatitis B virus infection among pregnant women were 16 (4.7\%) $(95 \% \mathrm{Cl} 2.7$, 7.7). Having a history of blood transfusion ( $A O R=5.2 ; 95 \% \mathrm{Cl} 1.2-22.3$ ), having a history of multiple sexual partners $(A O R=4.6 ; 95 \% \mathrm{Cl} 1.1-19.6)$ and having a history tonsillectomy (traditional surgical procedure) $(\mathrm{AOR}=3.4 ; 95 \% \mathrm{Cl}$ 1.1-10.1) were the significant risk factors for hepatitis B virus infection.
\end{abstract}

Keywords: Pregnant women, Bahir Dar, Ethiopia, Hepatitis B virus

\section{Introduction}

Hepatitis B virus (HBV) is a common cause of acute and chronic viral hepatitis worldwide. According to phylogenetic analyses, HBV can be classified into eight genotypes (A to $\mathrm{H}$ ) based upon an inter-group divergence. Among these, genotypes $\mathrm{B}$ and $\mathrm{C}$ are most common among those with chronic HBV, while genotype A is most common among those with acute HBV. Hepatitis B virus (HBV) is DNA virus causing hepatitis in humans which is classified as chronic hepatitis $B$ and acute hepatitis B virus infection. Acute hepatitis B in pregnancy is not associated with increased abortion rate, stillbirth, or congenital

*Correspondence: gedefawget@gmail.com

${ }^{1}$ Department of Midwifery, College of Health Sciences, Woldia University, Woldia, Ethiopia

Full list of author information is available at the end of the article malformation but higher incidence of low birth weight was reported [1].

Hepatitis B virus (HBV) is transmitted by vertical transmission, between family members within households by contact of non-intact skin or mucous membrane with secreting or saliva containing, unsafe sexual intercourse, transfusion of HBV infected blood and blood products, perinatal transmission, horizontal transmission, nosocomial infection(commonly transmitted blood-borne virus in the healthcare setting), and percutaneous inoculation (contaminated medical equipment and sharing of contaminated syringes and needles among injecting drug users) [2]. Perinatal and early childhood transmissions are the main routes of HBV infection in endemic areas. The risk of HBV infection transmission decreases where there is periodic perinatal HBV screening, immunoprophylaxis given infants born with HBV infected 
mother and hepatitis vaccine given both to the high risk mother and the newborn. Therefore, administration of hepatitis B immunoglobulin (HBIG) in combination with hepatitis $B$ vaccines as post exposure prophylaxis is very important since vertical transmission rate is nearly $100 \%$ [3]. Ethiopia is now identifying the magnitude of the problem and implementing the vaccination for health workers but still there is no accessibility and availability of vaccination of hepatitis $B$ virus for those healthy mothers. Hence, this study aimed to determine the magnitude and associated factors of hepatitis B surface antigen virus among pregnant women attending antenatal care at Felegehiwot referral hospital, 2018.

\section{Main text}

\section{Methods and materials}

Study setting

Bahir Dar town is located in Amhara region, $565 \mathrm{~km}$ north-west of Addis Ababa. According to 2007 Ethiopian central statistical agency report, the total populations of Bahir Dar town administration is 221, 991. Of them 108,456 are males and 113,535 females. The hospital has different departments that provide specialized services in outpatient, inpatient and operation theatre departments. It provides services for approximately for more than 7 million people from the surrounding area. It has more than 415 beds and gives services for the western part of Amhara region as a referral hospital. There are more than 600 members of staff employed by the hospital and a further 200 employed by Bahir Dar university. Felegehiwot referral hospital provides care for the pregnant mothers widely in ANC, intrapartum and postpartum period. HBV screening is given for all pregnant mothers who had antenatal care follow up since it is one of the routine investigations during their first ANC follow up but free vaccination is not started yet.

\section{Source population}

All pregnant women who had antenatal care follow up at Felegehiwot referral hospital.

\section{Study population}

All pregnant women who were visited the antenatal care clinic during the first visit at Felegehiwot referral hospital.

Inclusion criteria Women who had first antenatal care follow up at Felegehiwot hospital during the study period.

Exclusion criteria Women whose antenatal care follow up were in other health institutions.

Women who referred from other health institutions.

Women who have been vaccinated HBV.

\section{Study design and sample size determination}

We designed an institutional based cross-sectional study to estimate magnitude of hepatitis B virus infection. The sample size was estimated using Epi Info 7 software using sample size determination for cross sectional studies. The parameters that were used to estimate the sample size were: confidence level of $95 \%, 5 \%$ margin of error and prevalence of outcome was $7.8 \%$. The sample size was estimated by considering the prevalence of hepatitis B virus infection which was conducted in Hawassa hospital, Ethiopia. The sample size was 338 pregnant women.

\section{Sampling techniques and procedures}

Systematic random sampling technique was applied to select the study participants. We took 3 months' average sampled population from registration book which was done at ANC clinic which is 626. To get kth interval $=$ (source population $) \mathrm{N} /$ sample size $\left(\mathrm{n}_{0}\right)=626 / 338 \approx 2$. Then the first pregnant mother was randomly selected by lottery method. Then study participants were interviewed every two interval until the sample size was completed through systematic random sampling technique.

\section{Data collection tools and procedures}

Data collection was implemented both face to face interview through pretested structured questionnaire and chart review. A pre-tested structured questionnaire was consisting of socio-demographic and socioeconomic characteristics, risky socio cultural and behavioral factors, institution related factors and blood sample test was designed to collect patient serum hepatitis B surface antigen virus status by requesting laboratory investigation. One-day training was given for the supervisor and data collectors about data collection and sampling technique. There were two trained diploma midwives participated for data collection. Pre test was done to assess the content and face validity of the questionnaires. The investigator and supervisor made spot checking and reviewing the completed questionnaires on daily basis to ensure completeness and consistency of the information collected.

\section{Laboratory methods}

Blood sample was obtained from 338 pregnant women. A standard procedure was used to collect blood and process them for testing. All sera were screened for hepatitis B surface antigen (HBsAg) using Enzyme Linked Immunosorbent Assay (ELISA) (Hepanostika rapid kit test; 
Biomerieux, Boxtel, Netherlands with a sensitivity of $100 \%$ and specificity of $99.7 \%$ ) in central laboratory which is found in Felegehiwot specialized Hospital compound.

\section{Data processing and analysis}

After declaring for completeness and consistency of the data, the data were entered into Epi Info version-7 and exported into SPSS version 23 statistical software for data cleaning, coded and analysis. Bivariate logistic regression analysis was done after dichotomizing the dependent variables. After checking associations of the variables, those with $\mathrm{p}<0.2$ in bivariate analysis was processed to multi-variable logistic regression analysis to control confounding factors. $p$ value of $<0.05$ was used to express the statistical significance of the variables.

\section{Results}

\section{Socio-demographic and socio economic characteristics}

A total of 338 pregnant women were participating with a response rate of $100 \%$. The mean age of the women was 26.84 years (ranged from 22 to 40 years) with a SD of \pm 4.8 years. Two hundred sixty (76.9\%) respondents were urban in residence. Regarding marital status, 327 (96.7) of them were getting married. 320 (94.6\%) of the study participants had family history of HBV and 212 $(62.7 \%)$ of them were multigravida women (Additional file 1: Table S1).

Risky socio cultural, behavioral and institution related factors A total of $20(5.9 \%)$ participants had been history of blood transfusion, while 92 (27.2\%) had been hospitalized at some time during their lives. Among respondents 22 (6.5\%) had a history of unprotected multiple sexual partners and 97 (28.7\%) had a history of traditional tonsillectomy. No one was HIV positive among the study HBV positive participants (Table 1).

\section{Magnitude of HBV infection}

A total of $16(4.7 \%)$ with $(95 \%$ CI $2.7,7.7)$ respondents were found to be positive for $\mathrm{HBV}$ infection. A total of $8(5.3 \%)$ respondent's was observed in the age group of 26-30 years. Five (19.2\%) respondents were reported in daily laborers. None of the respondents were positive among HBV vaccinated women (Table 2).

\section{Risk factors associated with hepatitis $B$ virus infection}

Both bivariate and multivariable logistic regression analyses (backward conditional selection) were done to assess socio demographic and other predictable variables in relation to hepatitis B infection of the pregnant women. In bivariate analysis residency, educational status, previous place of birth, number of pregnancy, history of blood transfusion, history of body tattooing,
Table 1 Distribution of risky cultural, behavioral and institution related factors related to $\mathrm{HBV}$ infection among pregnant women attending antenatal care clinic at Felegehiwot referral Hospital from February to May, 2018, $(n=338)$

\begin{tabular}{|c|c|c|c|}
\hline \multirow[t]{2}{*}{ Characteristics } & \multicolumn{3}{|c|}{ HBV status of the mother } \\
\hline & Frequency (\%) & Positive (\%) & Negative (\%) \\
\hline \multicolumn{4}{|c|}{ History of blood transfusions } \\
\hline Yes & $20(5.9)$ & $3(15.0)$ & $17(85.0)$ \\
\hline No & $318(94.1)$ & $13(4.1)$ & 305 (95.9) \\
\hline \multicolumn{4}{|c|}{ History of dental extraction } \\
\hline Yes & $30(8.9)$ & $1(3.3)$ & $229(90.7)$ \\
\hline No & $308(91.1)$ & $15(4.9)$ & $293(95.1)$ \\
\hline \multicolumn{4}{|c|}{ History of surgical procedure } \\
\hline Yes & $41(12.1)$ & $1(2.4)$ & $40(97.6)$ \\
\hline No & $297(87.9)$ & $15(5.1)$ & $282(94.9)$ \\
\hline \multicolumn{4}{|c|}{ History of abortion or miscarriage } \\
\hline Yes & $78(23.1)$ & $4(5.1)$ & $74(94.9)$ \\
\hline No & $260(76.9)$ & $12(4.6)$ & $248(95.4)$ \\
\hline \multicolumn{4}{|c|}{ History of hospital admission } \\
\hline Yes & $92(27.2)$ & $4(4.3)$ & $88(95.7)$ \\
\hline No & $246(72.8)$ & $12(4.9)$ & $234(95.1)$ \\
\hline \multicolumn{4}{|c|}{ History of circumcision/FGM } \\
\hline Yes & $283(83.7)$ & $13(4.6)$ & $270(95.4)$ \\
\hline No & $55(16.3)$ & $3(5.5)$ & $52(94.5)$ \\
\hline \multicolumn{4}{|c|}{ Sharing of sharp materials } \\
\hline Yes & $32(9.5)$ & $3(9.4)$ & $29(90.6)$ \\
\hline No & $306(90.5)$ & $13(4.2)$ & $293(95.8)$ \\
\hline \multicolumn{4}{|c|}{ History of unprotected multiple sexual partners } \\
\hline Yes & $22(6.5)$ & $3(13.6)$ & $19(86.4)$ \\
\hline No & $316(93.5)$ & $13(4.1)$ & $303(95.9)$ \\
\hline \multicolumn{4}{|c|}{ History of unsafe injection of drugs } \\
\hline Yes & $5(1.5)$ & $1(20.0)$ & $4(80.0)$ \\
\hline No & $333(98.5)$ & $15(4.5)$ & $318(95.5)$ \\
\hline \multicolumn{4}{|c|}{ History of body tattooed } \\
\hline Yes & $178(52.7)$ & $12(6.7)$ & $166(93.3)$ \\
\hline No & $160(47.3)$ & $4(2.5)$ & $156(97.5)$ \\
\hline \multicolumn{4}{|c|}{ History of nose piercing } \\
\hline Yes & $10(3)$ & $0(.0)$ & $10(100.0)$ \\
\hline No & $328(97)$ & $16(4.9)$ & $312(95.1)$ \\
\hline \multicolumn{4}{|c|}{ History of ear piercing } \\
\hline Yes & $320(94.7)$ & $16(5.0)$ & $304(95.0)$ \\
\hline No & $18(5.3)$ & $0(0.0)$ & $18(100.0)$ \\
\hline \multicolumn{4}{|c|}{ History of traditional tonsillectomy } \\
\hline Yes & $97(28.7)$ & $10(10.3)$ & $87(89.7)$ \\
\hline No & $241(71.3)$ & $6(2.5)$ & $235(97.5)$ \\
\hline
\end{tabular}

having history multiple sexual partners, history of unsafe drug injection, history of sharing of sharp materials and the history of traditional tonsillectomy were factors significantly associated with hepatitis B infection. 
Table 2 Distribution of HBV among pregnant women attending antenatal clinic by socio demographic characteristics at Felegehiwot referral hospital, May 2018, $(\mathrm{n}=338)$

\begin{tabular}{|c|c|c|c|}
\hline \multirow[t]{2}{*}{ Characteristics } & \multirow[t]{2}{*}{ Frequency (\%) } & \multicolumn{2}{|c|}{ Status of $\mathrm{HBV}$ of the mothers } \\
\hline & & Positive N (\%) & Negative (\%) \\
\hline \multicolumn{4}{|l|}{ Age (years) } \\
\hline $18-20$ & $35(10.4)$ & $2(5.7)$ & $33(94.3)$ \\
\hline $21-25$ & $83(24.6)$ & $3(3.6)$ & $80(96.4)$ \\
\hline $26-30$ & $152(45)$ & $8(5.3)$ & $144(94.7)$ \\
\hline $31-40$ & $68(20)$ & $3(4.4)$ & 65 (95.6) \\
\hline \multicolumn{4}{|l|}{ Residence } \\
\hline Rural & $78(23.1)$ & $7(9.0)$ & $71(91.0)$ \\
\hline Urban & $260(76.9)$ & $9(3.5)$ & $251(96.5)$ \\
\hline \multicolumn{4}{|l|}{ Religion } \\
\hline Orthodox & $296(87.6)$ & $13(4.4)$ & $283(95.6)$ \\
\hline Muslim & $32(9.5)$ & $3(9.4)$ & 29 (90.6) \\
\hline Protestant & $10(3)$ & $0(0.0)$ & $10(100)$ \\
\hline \multicolumn{4}{|l|}{ Marital status } \\
\hline Single & $1(0.3)$ & $0(0.0)$ & $1(100)$ \\
\hline Married & $327(96.7)$ & $16(4.9)$ & $311(95.1)$ \\
\hline Divorced & $10(3.0)$ & $0(0.0)$ & $10(100)$ \\
\hline \multicolumn{4}{|l|}{ Ethnicity } \\
\hline Amhara & $316(93.5)$ & $16(5.1)$ & $300(94.9$ \\
\hline Oromo & $9(2.7)$ & $0(0.0)$ & $9(100)$ \\
\hline Tigre & $7(2.1)$ & $0(0.0)$ & $7(100)$ \\
\hline Others & $6(1.8)$ & $0(0.0)$ & $6(100)$ \\
\hline \multicolumn{4}{|l|}{ Occupation } \\
\hline House wife & $163(48.2)$ & $8(4.9)$ & $155(95.1)$ \\
\hline Employed & $86(25.4)$ & $2(2.3)$ & $84(97.7)$ \\
\hline Merchant & $57(16.9)$ & $1(1.8)$ & $56(98.2)$ \\
\hline Daily laborers & $26(7.7)$ & $5(19.2)$ & $21(80.8)$ \\
\hline Student & $6(1.8)$ & $0(0.0)$ & $6(100)$ \\
\hline \multicolumn{4}{|l|}{ Educational level } \\
\hline No formal education & $71(21.0)$ & $8(11.3)$ & $63(88.7)$ \\
\hline Primary & $68(20.1)$ & $4(5.9)$ & $64(94.1)$ \\
\hline Secondary & $82(24.3)$ & $1(1.2)$ & $81(98.8)$ \\
\hline College and above & $117(34.6)$ & $3(2.6)$ & $114(97.4)$ \\
\hline \multicolumn{4}{|l|}{ Monthly income } \\
\hline$<1000$ ETB & $20(5.9)$ & $1(5.0)$ & $19(95.0)$ \\
\hline 1000-1500 ETB & $32(9.5)$ & $3(9.4)$ & $29(90.6)$ \\
\hline $1501-2300$ ETB & $34(10.1)$ & $1(2.9)$ & $33(97.1)$ \\
\hline$>2300$ ETB & $252(74.5)$ & $11(4.4)$ & $241(95.6)$ \\
\hline \multicolumn{4}{|l|}{ Previous place of birth } \\
\hline Health facility & $159(47)$ & $9(5.7)$ & $150(94.3)$ \\
\hline Home & $52(15.4)$ & $4(7.7)$ & $48(92.3)$ \\
\hline TBA & $0(0.0)$ & $0(0.0)$ & $0(0.0)$ \\
\hline No birth & $127(37.6)$ & $3(2.4)$ & $124(97.6)$ \\
\hline \multicolumn{4}{|l|}{ No pregnancy } \\
\hline Primigravida & $104(30.8)$ & $2(1.9)$ & $102(98.1)$ \\
\hline Multigravida & $212(62.7)$ & $12(5.7)$ & $200(94.3)$ \\
\hline
\end{tabular}

Table 2 (continued)

\begin{tabular}{lccc}
\hline Characteristics & Frequency (\%) & \multicolumn{2}{c}{ Status of HBV of the mothers } \\
\cline { 3 - 4 } & & Positive N (\%) & Negative (\%) \\
\hline $\begin{array}{l}\text { Grand multigravida } \\
\text { HBV vaccination status }\end{array}$ & $22(6.5)$ & $2(9.1)$ & $20(90.9)$ \\
Yes & $17(5)$ & $0(0.0)$ & $17(100)$ \\
No & $321(95)$ & $16(5.0)$ & $305(95)$ \\
Knowledge about way of transmission of HBV & \\
Yes & $41(12.1)$ & $0(0.0)$ & $41(100)$ \\
No & $297(87.9)$ & $16(5.4)$ & $281(94.6)$ \\
\hline
\end{tabular}

Under multivariable logistic regression analysis showed that three predictor variables were statistically significant associated with HBV infections.

Pregnant women who had history of blood transfusion were 5.2 times more likely of being infected by HBV than pregnant women who had no history of blood transfusion $[\mathrm{AOR}=5.2 ; 95 \%$ CI 1.2-22.3, $\mathrm{p}$-value $=0.03]$.

Having a history of multiple sexual partners were 4.6 times more likely to be infected by $\mathrm{HBV}[\mathrm{AOR}=4.6 ; 95 \%$ CI 1.1-19.6, p-value $=0.04$ ] than women who were living with their partner.

Pregnant women who had a history of traditional tonsillectomy were about 3.4 times more likely of being infected than those had no history of traditional tonsillectomy $[\mathrm{AOR}=3.4 ; 95 \%$ CI $1.1-10.9, \mathrm{p}$-value $=0.03]$ (Table 3).

\section{Discussion}

Hepatitis B virus infection is a public health problem and a major cause of morbidity and mortality, particularly in developing countries [4].

In this study found to be that the magnitude of $\mathrm{HBsAg}$ among study participants were 16 (4.7\%) (95\% CI 2.7, 7.7) with a response rate of $100 \%$. According to established criterion, the prevalence of $\mathrm{HBsAg}$ among pregnant women in this study area can be classified as an intermediate category [5].

This finding is in line with different studies were done with a proportion of 5.3\% in Debre Tabor general hospital [6], 5.5\% in Tigray [7], 3\% St. Paul's millennium medical college and Selam health center [8], 3.7\% in Jimma [9], 6.9\% in Deder hospital, eastern Ethiopia [10], 7.3\% in Gondar health center [11], and 4.9\% in Dessie Referral hospital [12]. This might be due to the sampling method, risky socio cultural and risky behavioral practice and methods used to screen HBsAg infection were the same.

But, relatively it is higher than $2.5 \%$ of prevalence which were reported from three public hospitals in 
Table 3 Factors associated with HBV infection among pregnant women attending antenatal clinic at Felegehiwot referral hospital, Bahirdar, North West, Ethiopia, 2018, $(n=338)$

\begin{tabular}{|c|c|c|c|c|c|}
\hline \multirow[t]{2}{*}{ Characteristics } & \multicolumn{4}{|c|}{ HBV status of the mothers } & \multirow[t]{2}{*}{ p-value } \\
\hline & Positive \% & Negative \% & COR $(95 \% \mathrm{Cl})$ & AOR/ $(95 \% \mathrm{Cl})$ & \\
\hline \multicolumn{6}{|l|}{ Residence } \\
\hline Rural & 7 & 71 & $0.4(0.2,1.1)$ & $0.6(0.2,2.1)$ & 0.34 \\
\hline Urban & 9 & 251 & 1 & 1 & \\
\hline \multicolumn{6}{|l|}{ Educational level } \\
\hline No formal education & 8 & 63 & $0.2(0.1,0.9)$ & $0.3(0.1,1.2)$ & 0.09 \\
\hline Primary & 4 & 64 & $0.5(0.1,1.2)$ & $0.6(0.1,2.6)$ & 0.42 \\
\hline Secondary & 1 & 81 & $2.2(0.3,20.9)$ & $2.6(0.3,23.2)$ & 0.5 \\
\hline College and above & 3 & 114 & 1 & 1 & \\
\hline \multicolumn{6}{|l|}{ Previous place of birth } \\
\hline Health facility & 9 & 150 & $0.8(0.3,2.5)$ & $1.1(0.2,9.6)$ & 0.98 \\
\hline Home & 4 & 48 & $2.5(0.7,9.4)$ & $1.5(0.2,19.8)$ & 0.78 \\
\hline No birth & 3 & 124 & 1 & 1 & \\
\hline \multicolumn{6}{|l|}{ No of pregnancy } \\
\hline Primigravida & 2 & 102 & 1 & 1 & \\
\hline Multigravida & 12 & 200 & $0.33(0.07,1.49)$ & $0.6(0.2,3.3)$ & 0.53 \\
\hline Grand multigravida & 2 & 20 & $0.20(0.03,1.48)$ & $0.9(0.1,8.9)$ & 0.89 \\
\hline \multicolumn{6}{|c|}{ History of blood transfusions } \\
\hline Yes & 3 & 17 & $4.2(1.08,16)$ & $5.2(1.2,22.3)$ & $0.03^{*}$ \\
\hline No & 13 & 305 & 1 & 1 & \\
\hline \multicolumn{6}{|c|}{ History of sharing sharp materials } \\
\hline Yes & 3 & 29 & $2.4(0.7,8.7)$ & $1.2(0.3,5.1)$ & 0.81 \\
\hline No & 13 & 293 & 1 & 1 & \\
\hline \multicolumn{6}{|c|}{ History of unprotected multiple sexual partners } \\
\hline Yes & 3 & 19 & $3.7(1,14.1)$ & $4.6(1.1,19.6)$ & $0.04^{*}$ \\
\hline No & 13 & 303 & 1 & 1 & \\
\hline \multicolumn{6}{|c|}{ History of unsafe injection of drugs } \\
\hline Yes & 1 & 4 & $5.3(0.6,50.4)$ & $6.5(0.6,76.8)$ & 0.2 \\
\hline No & 15 & 318 & 1 & 1 & \\
\hline \multicolumn{6}{|l|}{ History of body tattooed } \\
\hline Yes & 12 & 166 & $2.9(1,9)$ & $1.6(0.5,6)$ & 0.5 \\
\hline No & 4 & 156 & 1 & 1 & \\
\hline \multicolumn{6}{|c|}{ History of traditional tonsillectomy } \\
\hline Yes & 10 & 87 & $4.5(1.6,12.8)$ & $3.3(1.1,10.1)$ & $0.03^{*}$ \\
\hline No & 6 & 235 & 1 & 1 & \\
\hline
\end{tabular}

${ }^{*} p<0.05$

Addis Ababa [13]. This difference might be due to risky socio cultural and behavioral practices were low. However, it is lower than the study conducted in Hawassa referral hospital 7.8\% [14]. This difference might be due to the methods used to screen highly sensitive and specific and risky socio cultural and behavioral practiced were high.

However, higher results were reported in Mali 8\% [15], Yemen 10.8\% [16], Uganda 11.8\% [17], Nigeria $12 \%$ [18] and Kenya 14.1 [19]. This variation might be due to differences in sampling method, geographical variation, cultural and behavioral differences regarding possible risk factors of $\mathrm{HBV}$ infection, and differences in the test methods employed to detect $\mathrm{HBV}$ infection.

Whereas, lower prevalence $0.14 \%$ to $0.97 \%, 0.9 \%, 1 \%$, $1.5 \%, 1.6 \%$ and $2.1 \%$ were reported in USA [20], Brazil [21], Kenya [22], Libya [3], Saudi Arabia [23] and North Turkey [15], respectively. This variation may be due to in developed nations, where regular screening and vaccination for HBV were performed. 
Having history of tonsillectomy (traditional surgical procedure) was an independent risk factor associated with HBV. This study finding is similar with the study done in different places of Ethiopia Deder [10], Dessie [12] and Nigeria [18]. This finding may be explained as this surgical procedure is performed via traditional manner where no sterilization technique used. Therefore, the virus is easily transmitted from the career to the healthy mother.

In this study having a history of blood transfusion was an independent risk factor for hepatitis B virus infection. The finding of this study is similar with the study done in Tanzania [24], Debre Markos, Northeast Ethiopia [25]. This is explained as due to the fact that hepatitis B virus is transmitted through any fluid/mucosal/blood contact from infected patients easily.

Women who had history of multiple sexual partners have high chance to be infected by hepatitis B virus infection than the counter parts. This study finding is consistent with the study done in northern Ethiopia [6], Deder [10], and Nigeria [12]. This finding may be explained as since hepatitis virus is blood born virus; blood, semen and other body fluids are primary source of infection that sexual contacts provide as mode of transmission.

\section{Conclusion}

This study revealed that the magnitude of HBV infection was low. Having history of blood transfusion, having history of multiple sexual partners and having history of tonsillectomy (traditional surgical procedure) were significantly associated variables with $\mathrm{HBV}$ infection. Avoiding cultural malpractice, ensuring sterility while taking blood for transfusion and create awareness in the community about the transmission and prevention methods may decrease the magnitude of hepatitis B surface antigen virus infection.

\section{Limitation}

This study was the inability to use more sensitive diagnostic methods like polymerase chain reactions, which would have help detecting occult HBV infection.

\section{Additional file}

Additional file 1: Table S1. Socio demographic characteristics of pregnant women attending antenatal clinic at Felegehiwot referral hospital, May $2018(n=338)$.

\section{Abbreviations}

AIDS: Acquired Immunodeficiency Syndrome; ANC: Antenatal Clinic; AOR: adjusted odd ratio; APHI: Amhara public Health Institution; BSc: Bachelor of Science; CDC: Center for Disease Control; COR: crude odd ratio; DNA: deoxyribonucleic acid; ELISA: Enzyme Linked Immunosorbent Assay; FGM: female genital mutilation; HBeAg: hepatitis B "e" antigen; HBsAg: hepatitis B surface antigen; HBV: hepatitis B virus; HCV: hepatitis C virus; HIV: human immunodeficiency virus; IEC: Information Education Communication; MSc: Masters of Science; SPSS: Statistical Package for Social Science; USA: United States of America; WHO: World Health Organization.

\section{Acknowledgements}

First of all, we would like to forward our deepest gratitude to Bahir Dar University, college of medicine and health science for financial support to conduct this research and APHI was given the official permission letter. Our special thanks and appreciation goes to all the study participants who voluntarily participated in this study and health care personnel of the FHRH and for their consistent support.

\section{Authors' contributions}

FW wrote the proposal, participated in data collection, analyzed the data and drafted the paper. FW, GG, AA, and KG approved the proposal with some revisions, participated in data collection, analysis and manuscript writing. All authors read and approved the final manuscript.

\section{Funding}

Bahir Dar University. The funder has no any role for designing of the study, collection analysis, and interpretation of the data and writing up of the manuscript.

\section{Availability of data and materials}

All related data has been presented within the manuscript. The data set supporting the conclusions of this article is available from the authors on request.

\section{Ethics approval and consent to participate}

Ethical clearance was obtained from the ethical review committee of Bahir Dar University College of medicine and health science. Permission letter was obtained from Amhara regional health bureau and also asked from Felegehiwot comprehensive specialized Hospital. Then the objective of the study was explained to the identified study subjects. Written informed consent had applied when collecting data from pregnant women attending routine antenatal clinics. Anonymity was maintained by using identity numbers instead of patient names. Beside, all the data abstracted was kept confidential and not used for any other purposes than the stated research objective.

\section{Consent to publish}

Not applicable.

\section{Competing interests}

The authors declare that they have no competing interests.

\section{Author details}

${ }^{1}$ Department of Midwifery, College of Health Sciences, Woldia University, Woldia, Ethiopia. ${ }^{2}$ Department of Midwifery, College of Medicine and Health Sciences, Bahirdar University, Bahirdar, Ethiopia.

Received: 18 July 2019 Accepted: 10 August 2019

Published online: 15 August 2019

\section{References}

1. Sookoian DS, Hepatitis B. Virus and pregnancy. Instit Med Res. 2017;5:12.

2. Stephen A, et al. Hepatitis in pregnancy. Medscape. 2016;3:435-9.

3. El-Magrahe $\mathrm{H}$, et al. Maternal and neonatal seroprevalence of Hepatitis B surface antigen (HBsAg) in Tripoli, Libya. J Infect Dev Ctries. 2010;4(3):168-70.

4. European Association for the Study of the Liver. Clinical Practice Guidelines on the management of hepatitis B virus infection. J Hepatol. 2017;67:370-98.

5. WHO. Guidelines for the prevention, care and treatment of persons with chronic hepatitis B infection. WHO. 2015;27:166.

6. Walle F, et al. Prevalence of hepatitis B surfaces antigen among pregnant women attending antenatal care service at Debre-Tabor Hospital, Northern Ethiopia. Ethiopia J Health Sci. 2008;17(1):13-20. 
7. Tadele A, et al. Hepatitis B virus infection and associated risk factors among pregnant women attending antenatal care in health facility of Tigray, northern Ethiopia. Med Virol. 2017;90:503-9.

8. Dessie T, et al. Seroprevalence and transmission of Hepatitis B virus among elivering women and their new born in selected health facilities, Addis Ababa, Ethiopia. BMC Res Notes. 2014;7:239.

9. Mohamed A. Seroprevalence of HBsAg and its risk factors among pregnant women in Jimma, southern Ethiopia. Ethiop J Health Dev. 2003;19:45.

10. Abdi UBS, Tesfaye G, Tamirat HM. Hepatitis B virus infections and associated factors among pregnant women attending antenatal care clinic at Deder Hospital, Eastern Ethiopia. PLoS ONE. 2015;11:11.

11. Tiruneh M. Seroprevalence of multiple sexually transmitted infections among antenatal clinic attendees in Gondar Health Center, northwest Ethiopia. Ethiop Med J. 2008;46(4):359-66.

12. Seid M, Gelaw B, Assefa A. Sero-prevalence of HBV and HCV infections among pregnant women attending antenatal care clinic at Dessie Referral Hospital, Ethiopia. Adv Life Sci Health. 2014;1(2):109-20.

13. Ayele AG, Solomon G-S. Prevalence and risk factors of hepatitis B and hepatitis $C$ virus infections among patients with chronic liver diseases in public hospitals in Addis Ababa, Ethiopia. ISRN Trop Med. 2013;2013:7.

14. Metaferia Yeshi, Ali Ibrahim, Amsalu Anteneh. Seroprevalence and associated risk factors of hepatitis B virus among pregnant women in southern Ethiopia. Epidemiol Health. 2015;38:7.

15. Brett MRF, Edward B, Joseph K, Daoda D, Amy C, et al. Seroprevalence of hepatitis B surface antigen among pregnant women attending the Hospital for Women \& Children in Koutiala, Mali. S Afr Med J. 2012:102:47-9.

16. Entisar AMSM, Gasim IG, Duria AR, Ishag A. Epidemiology of hepatitis B and hepatitis C virus infections in pregnant women in Sana'a, Yemen. BMC Pregn Childbirth. 2013;13:127.

17. Pontius BEO, Caroline $O$, Amos DM. High prevalence of hepatitis B virus infection among pregnant women attending antenatal care: a cross-sectional study in two hospitals in northern Uganda. BMJ Open. 2014;4:1136.
18. Emmanuel M, Mbaawuaga CUI, Anthony Cl, Gabriel T, Aondohemba J. Studies on prevalence, co-infection and associated risk factors of hepatitis $B$ virus (HBV) and Human immunodeficiency virus (HIV) in Benue State, Nigeria. Sci J Public Health. 2014;2(6):569-76.

19. Mohammed AA. Prevalence and risk factors for hepatitis B infection among pregnant women attending antenatal clinics in Garissa district. Doctoral dissertation, Laboratory Management and Epidemiology, JKUAT.

20. Euler GL, Baughman AL, Williams WW. Hepatitis B surface antigen prevalence among pregnant women in urban areas: implications for testing, reporting, and preventing perinatal transmission. Pediatrics. 2003;111:1192-7.

21. Souza MTPT, Santos MDC, Santos A, Monteiro VL, Fonsêca LMB, et al. Prevalence of hepatitis $B$ among pregnant women assisted at the public maternity hospitals of São Luís, Maranhão, Brazil. Braz J Infect Dis. 2012;16(6):517-20.

22. Ngerecia JN. Seroprevalence of Hepatitis B surface antigen and its associated factors among HIV positive pregnant women in Jaramogi Oginga Odinga Teaching and Referral Hospital (JOOTRH) Kisumu. KNH/UoN-ERC. 2016;5:80.

23. Alrowaily AAMA, Ferwanah MS. Hepatitis B virus sero prevalence among pregnant females in Saudi Arabia. Saudi J Gastroenterol. 2008;14(2):70-2.

24. Elichilia $R$, et al. Seroprevalence of hepatitis B virus infection and associated factors among healthcare workers in northern Tanzania. BMC Infect Dis. 2018;18:95-109.

25. Bialfew $X$, et al. Prevalence and associated factors of Hepatitis b virus infection among blood donors in Debre Markos blood bank center, northeast Ethiopia. Epidemiology. 2018:8:363.

\section{Publisher's Note}

Springer Nature remains neutral with regard to jurisdictional claims in published maps and institutional affiliations.
Ready to submit your research? Choose BMC and benefit from:

- fast, convenient online submission

- thorough peer review by experienced researchers in your field

- rapid publication on acceptance

- support for research data, including large and complex data types

- gold Open Access which fosters wider collaboration and increased citations

- maximum visibility for your research: over $100 \mathrm{M}$ website views per year

At BMC, research is always in progress.

Learn more biomedcentral.com/submissions 